\title{
地震工学・土木
}

運輸省港湾技術研究所林聡

(昭和 41 年 2 月 11 日受理)

\section{Earthquake Engineering-Civil Engineering Structures}

\section{Satoshi HAYASHI}

Port and Harbour Research Institute, Ministry of Transport

(Received Fev. 11, 1966)

\section{1. 土木構造物の耐震設計法}

\section{1-1 震 度 法}

土木構造物の耐震設計には一般に「震度法」が用いられている。震度法は 1914 年佐野博士1) によつてはじめて耐震設計に導入され, 現在に至るまで用いられている.

佐野博士によれば, 弾性变形の少ない構造物に働く地震力の大きさほ, 構造物の質量 $m$ と, 地震動の加速度 $\alpha$ との積であらわされ, その方向は, 地動加速度と反対方向に働くとされて いる. すなわち, 耐震設計上は, 最大加速度 $\alpha_{m}$ が問題となり， $\alpha_{m}$ と重力の加速度 $g$ との 比 $\alpha_{m} / g=k$ を震度と名付けると, 先に定義された地震力は, 次のようにあらわされる.

$$
\alpha_{m} \cdot m=\alpha_{m} / g \cdot m g=k W
$$

なおここに $W$ は構造物の重量である。このように震度 $k$ によつて地震力をあらわし, 耐 震計算を行なう方法を震度法と称する.

また詳しく考察すると地震動の加速度には水平, 鉛直両成分があり, これらをとれぞれ $\alpha_{h}$, $\alpha_{v}$ とすると，そ机ぞれに対応する水平震度 $k_{h}$ および鉛直震度 $k_{v}$ は次のようになる.

$$
k_{h}=\alpha_{h} / g, \quad k_{v}=\alpha_{v} / g
$$

したがつて両者を同時に考慮するとき，合震度 $K$ は

$$
K=\frac{\alpha_{h}}{g \pm \alpha_{v}}=\frac{k_{h}}{1 \pm k_{v}}
$$

となる。

このように震度法によれば，地震時に起る最大地震力が，あたかも静的な力として常時作用

昭和 40 年 5 月 7 日地震学会で発表. 
するかのように考えて設計する訳であるから，このような計算方法と，実際に起つている現象 との差異をよく考慮に入れて設計を行なわなければならない、このような点を考慮した実際的 配慮の一例として, 地震時における材料の許容応力度, 安全率等学常時におけるそれ等と異な る值をとつている事実等が挙げられる。

また弾性変形やロッキングの影響が無視できない構造物の場合には，地盤の震度と同じ震度 が一様に働くと考学るのは不合理であつて, 構造物の動的応答效果, 震力分布等を考慮に入れ て震度法を適用しなければならない。

震度法をこのように適用する場合，これ蒁正震度法」とよぶことがある。

実在の構造物の耐震設計に際して, 修正震度法が適用された例として, 神戸港第 7 突堤およ び大船渡港防波堤をあげることができる。

神戸港第 7 突堤2) は図-1 に断面図を示すように，剛性の大きな脚柱によつて支えられた栈 橋構造上に 3 階建の上屋倉庫が一体となつて建設されており, 全高は $30 \mathrm{~m}$ 以上に及势構造物 である. 設計上の考え方として, この構造物の地震時の挙動として, 一次の剪断振動が爷配的 に誘起されると仮定して震度分布を定めた。このようにして得られた震度分布が図-1 の右側 に示されている.

大船渡港防波堤 ${ }^{3)}$ (水深 $30 \mathrm{~m}$ 以上の海底に設置され，津波の波高減殺を目的として建設さ れたもので, 図-2 に示すようにフィルタイプ構造上にケーソンを設置した全高 $40 \mathrm{~m}$ 以上に

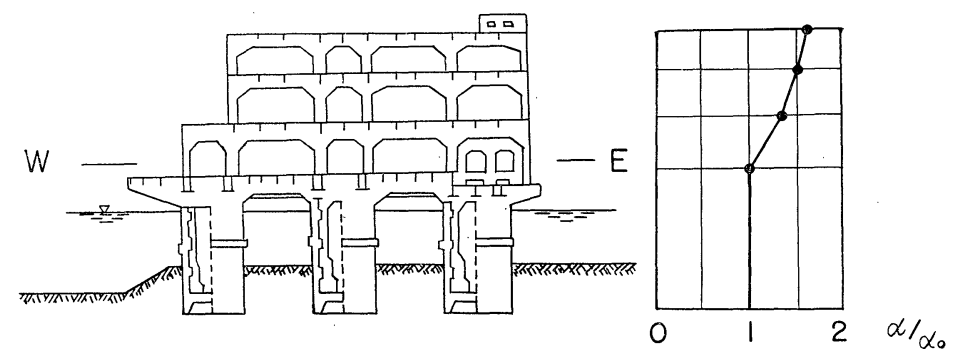

図-1

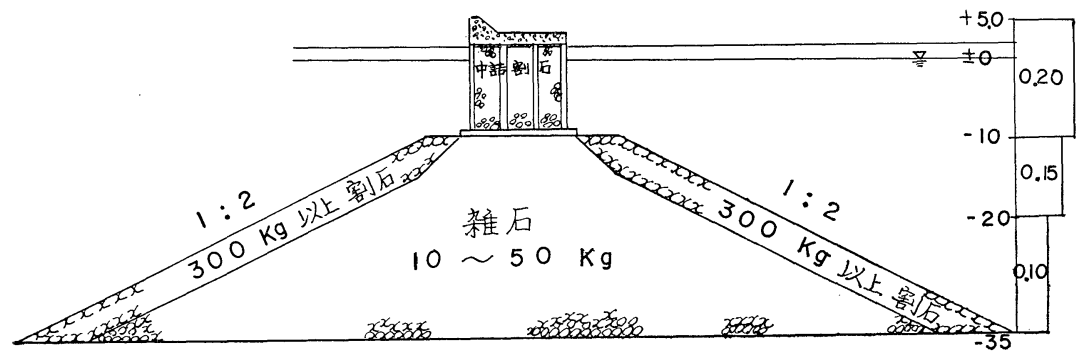

図-2 
およぶ構造であるため, 耐震性に関する慎重な考虑がはらわれている。この防波堤の設計震度 は図-2 の右側に示すような階段状の数值がとられている.

\section{1-2 動的設計法}

耐震設計は本来地震時の構造物の挙動と言う動的な現象を対象としているものであるが, 設計計算法の単純，簡便性のために震度法が用いられているが，構造物の種類によつてはこの ような方法では合理的に設計できないものもある。ここでいう動的設計法とは, 広義には前述 の修正震度法も含むが，普通にはより本格的な動力学的手法に基づく設計法もしくは解析法を 言うのであつて，主としてフレキシブルな構造物に適用する.フレキシブルな構造物とソリッ ドな構造物の区別は土木構造物の場合あまり簡単ではない，橋梁の場合はスパンの長さ，橋脚 の高さ, ダムや港湾構造物の場合は高さが判定の目安となる.

本質的には設計で考光ている地震の支配的な振動の周期と構造物の固有振動周期とのか敉合 いで判定すべきであろう。たとえば国鉄の土木構造物の設計基準4では，固有周期が 0.6 秒以 上のものを動的設計の対象としている.

動的設計乃至は解析の具体的方法の一つとして応答スペクトルによる方法を挙げることがで きる，応答スペクトル お5よびその利用法については現在ではよく知られている事柄であるの でここでは説明を省略するが，この方法を用いるためには相当数の強震記録が必要である。、 ウスナー等の米国の地震工学者は 1930 年以降主としてカリフォォルニア地方で起つたいくつ かの強震の加速度記録に対して応答スペクトル曲線它作成し，その「平均応答スペクトル曲線」 を作つた

日本では構造物に被害を及ぼす程度の強震記録の集積は充分でないが，1952 年 SMAC 型

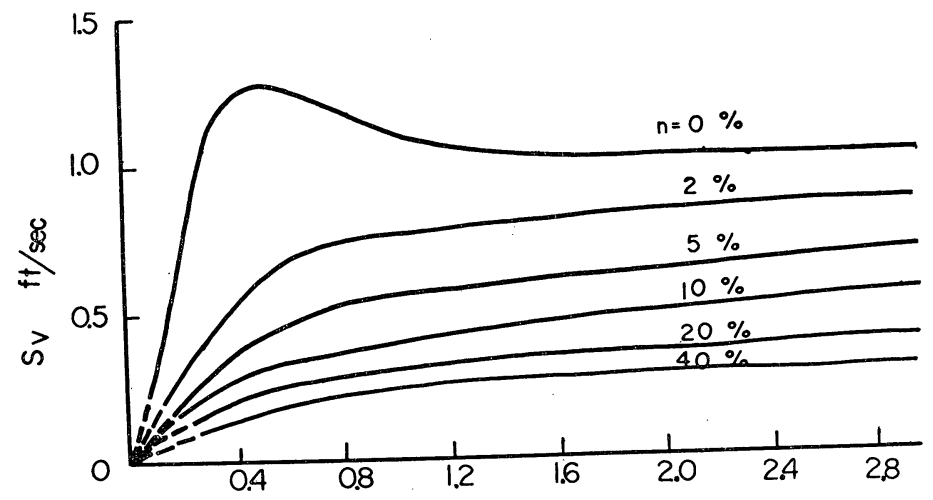

Period Sed

図 3 
強震計の設置が開始されて以来かなりの記録の蒐集が行なわれている，最近建設省土木研究 所? では 1959 年から 1964 年の間に日本国内拉よびその周辺で生じた 6 箇の地震の水平動 20 成分の平均動的係数 $\beta_{\mathrm{av}}$ のスペクトルの包絡線を作成した．乙れを図-4 に示す。 なお平均動 的係数 $\beta_{\mathrm{av}}$ とは $\beta=S_{A} / \ddot{Z}_{\max }$ の平均值, 寸なわち, 絶対加速度応答の最大值と地動加速度の 最大值との比の平均を示したものである。しかしながら応答スペクトルを実際の耐震設計に一 般的に利用するには強震記録の数が未だ不足している。したがつて現段階では応答スペクトル 法と実用設計の間に何等かの方法を介在させる必要があるとの意見がある。

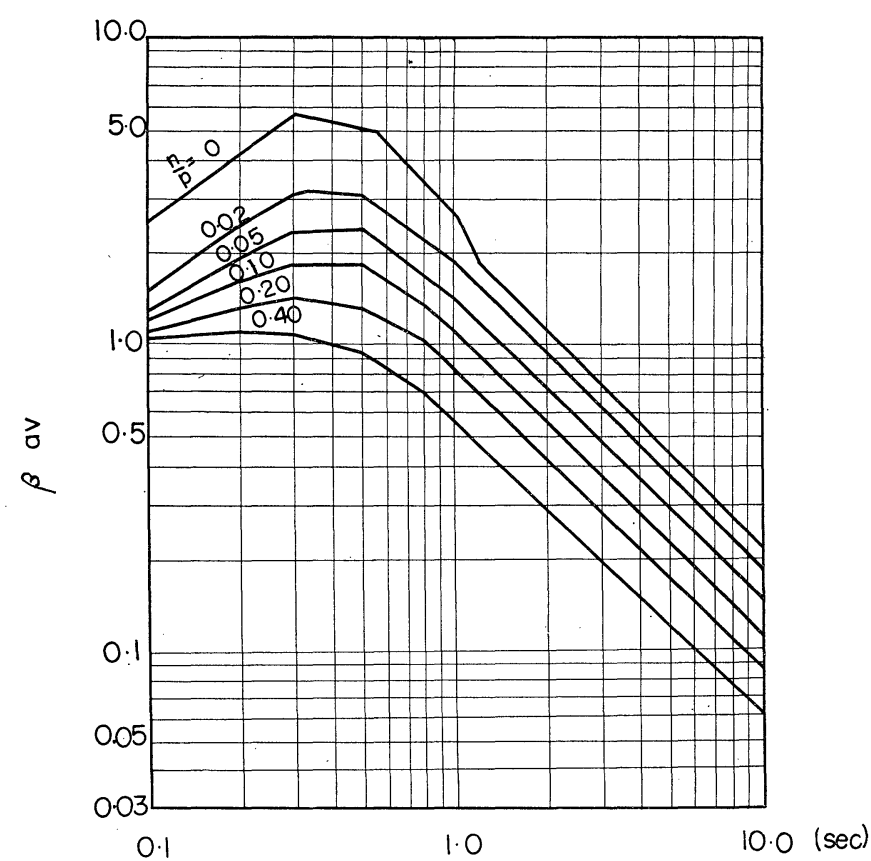

周 期 (T)

図 4

田治見 ${ }^{8)}$ は不規則な地震動の構造物への伝達の計算に統計的な手法を用い, 金井等の研究9) で代表される地盤特性を考虑した地震スペクトルを入力として取报つた。図-5 は金井の地動 スペクトル，図-6 は田治見による一質点系の加速度伝達率の計算例をあらわす。

上記の動的設計法を用いるにはいずれの場合にせよ構造物の固有振動周期と減衰係数がわか らなければならない，これらの振動特性を知る方法を確立するために各分野で盛えな研究が行 なわれているが，現在の段階では，既に建設された同種の構造物で類似の形状寸法，あるいは 地盤条件の構造物の実測結果を参考にする場合が多い. 


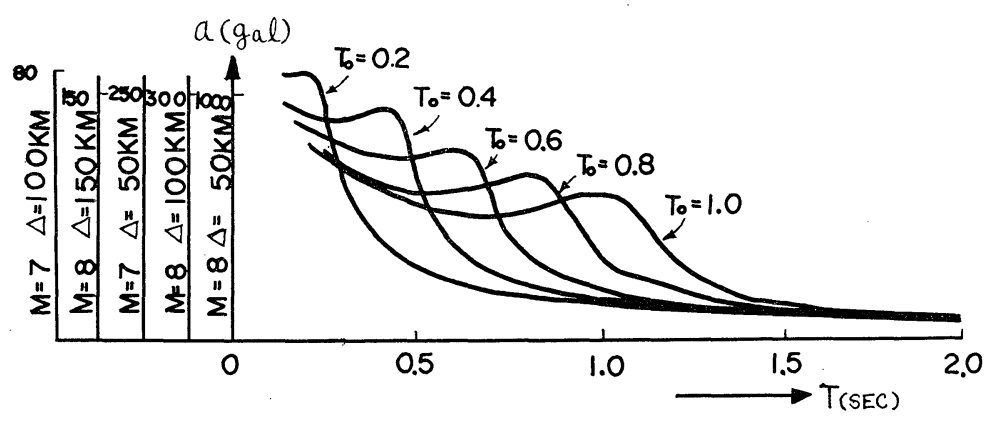

図 5

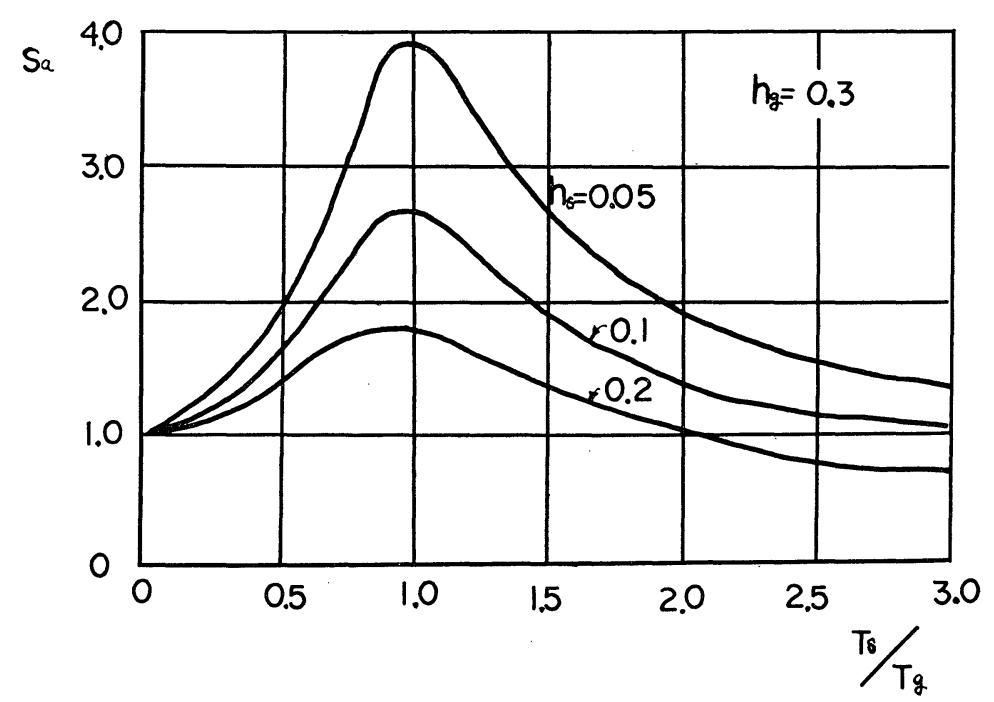

図-6

\section{1-3 各種土木構造物の耐震規定}

耐震規定の主な内容はそれぞれの土木構造物の設計震度をいかに定めるかと言う問題である が，設計震度の決定因子としては周知のように次のような多くの因子を挙げるととができる。 すなわち

（1）地震発生の地域的危険度

（2）地盤条件

（3）構造物の力学的特性

（4）構造物の重要性

（5）工事の経済性

（6）耐震設計計算の方法 
（7）材料（地盤を含导）の許容応力度

それぞれの構造物に対して，上記の因子のうちいくつかを組合せて設計震度が定められる. 各種土木構造物の耐震規定の概要は次の通りである.

1) ダム

ダムの設計に関する地震力規定は 1957 年「大ダム日本国内委員会」によつて定められ，ダ ムの自重に設計震度を乗じて求められた地震力と地震時動水圧を考慮するよう定められてい る. 設計震度は水平方向のみ考慮し, 構造物の種類と地域とを考慮した表-1 に定められた值 を基準とし，空虚時は表-1 の設計震度の半分をとればよいとされている．またコンクリート ダムの場合，耐震設計のさいの許容応力度の増分は $15 \%$ とされている.

表-1 ダムの設計 震 度

\begin{tabular}{|c|c|c|}
\hline 構 造 種 別 & 地 & 域 \\
\hline & $\begin{array}{l}\text { 東北地方（福島県, 秋田県, 宮城県) } \\
\text { 関東地方 } \\
\text { 中部地方 } \\
\text { 近畿地方 } \\
\text { 南四国地方 }\end{array}$ & $\begin{array}{l}\text { 北海道地方 } \\
\text { 北 陸 地方 } \\
\text { 東北地方 (岩手県, 山形県, 青森県) } \\
\text { 北四国地方 } \\
\text { 九 州 地方 }\end{array}$ \\
\hline $\begin{array}{l}\text { コンクリートダム } \\
\text { ロックフイルダム }\end{array}$ & $0.10 \sim 0.20$ & $0.10 \sim 0.15$ \\
\hline アースダム & $0.15 \sim 0.25$ & $0.10 \sim 0.20$ \\
\hline
\end{tabular}

2) 水道施設

日本水道協会は 1953 年に「水道施設の耐震工法」を刊行し，この中に水道施設の耐震規定 が述ベられている。

水道施設の設計震度は地域, 地盤, 施設の別により次のように定められている。すなわち, 各地域における標準震度は図-7 に示す值をとる。ただし, 図-7 は河角博士の 75 年震度期待 值分布図である。また構造物に対する設計震度は，地盤の種類，施設の種別によつて，標準震 度に表-2 に示す比率を乗じた值とする。なおこの值が 0.1 以下になる場合は 0.1 とし，0.3 をこえるときは 0.3 とすることができる，ただし，塔状構造物，水管橋その他の特殊構造物 に対しては 0.4 以上とする。また地震荷重を考慮した場合のコンクリート，鉄筋などの許容 応力度は平時の 1.5 倍まで高めることができ, 地盤の許容支持力は, 岩盤に対しては 1.5 倍, 洪積層，沖積層に対しては常時と同じ值をとり，基礎杭の許容卖持力も常時の值から割増しを しない，地震時の動水圧の算定には Westergaadの近似式が通常用いられる。

3）鉄道土木施設 


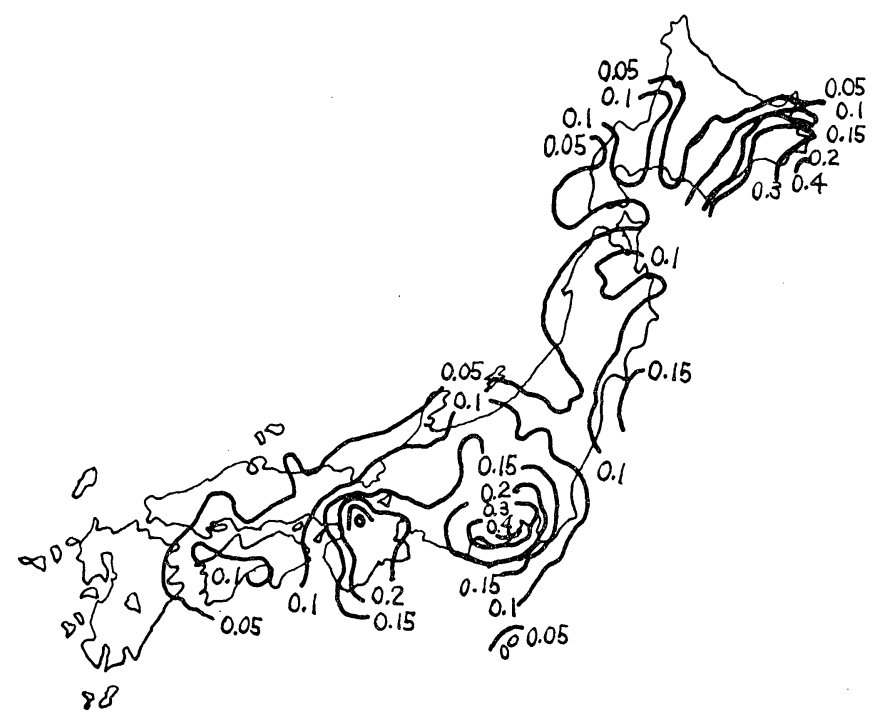

図-7

表-2 水道施設設計震度係数表

\begin{tabular}{|c|c|c|c|c|}
\hline 地 & 盤 種 別 & 浄水施設・水路 & 塔状構造物水管橋 & 地中埋設管 \\
\hline 岩盤, & 硬い砂レキ層 & 0.4 & 0.5 & 0.3 \\
\hline 洪 & 積＼cjkstart層 & 0.7 & 0.7 & 0.7 \\
\hline 沖 & 積 & 1 & 1 & 1 \\
\hline 軟 & 弱 地 盤 & 2 & 2 & 2 \\
\hline
\end{tabular}

日本国有鉄道の依頼により，土木学会は耐震構造設計研究委員会を設けて，昭和 40 年に 「土木構造物の耐震設計指針（案)」出) を作成した。これによると鉄道土木施設の耐震設計は一 般に震度法によることとし，水平震度は地域別，地盤別，重要度別を考慮して次のように定め ている.

\section{水平震度 $=$ 地域別震度 $\times$ 地盤種別係数 $\times$ 重要度係数}

鉛直震度を考える場合は，その值は水平震度の $1 / 2$ とするよう定めている，上記の地域別震 度は表 -3 に，地盤種別係数は表-4 に，地盤種別分類表を表 -5 に，重要度係数を表-6 にそれ ぞれ示す．また高さに対する震度の割増しの規定として，地上 $10 \mathrm{~m}$ 以上の部分に対しては， 高さ $1 \mathrm{~m}$ を増すごとに震度を $1 \%$ 増加させるよう定めている.

以上は一般の震度法を適用する範囲の耐震規定であるが，特に長径間橋りよう，高い橋脚等 のように，フレキシブルな構造物の場合には震度法によらず，動的解析（1-2）を行なうべき であるとされている。 
表-3 地域別震度（鉄道土木施設）

\begin{tabular}{|c|c|c|c|}
\hline A & 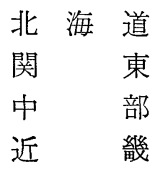 & $\begin{array}{l}\text { 根室, 釧路, 十勝 } \\
\text { 千葉, 埼玉, 東京, 神奈川 } \\
\text { 山梨, 長野, 静岡, 愛知, 岐阜 } \\
\text { 滋賀, 京都, 兵庫, 三重, 奈良, 大阪, 和歌山 }\end{array}$ & 0.2 \\
\hline B & & cの他の地域 & 0.15 \\
\hline
\end{tabular}

表-4 地般別係数（鉄道土木施設）

\begin{tabular}{|c|c|c|c|c|}
\hline 地 盤 種 別 & 第 1 種地盤 & 第 2 種地盤 & 第 3 種地盤 & 第 4 種地盤 \\
\hline 係 数 & 0.8 & 0.9 & 1.0 & 1.2 \\
\hline
\end{tabular}

表-4 地盤種別（鉄道土木施設）

\begin{tabular}{|c|c|c|c|c|c|c|c|c|c|c|c|c|}
\hline \multirow{3}{*}{$\frac{\text { 沖積層の厚さ }}{2 \mathrm{~m} \text { 以下 }}$} & \multirow{3}{*}{$\begin{array}{l}\text { 砂 } \\
\text { (扇 } \\
\text { 第 }\end{array}$} & \multirow{3}{*}{$\frac{v}{\text { 状 }}$} & \multirow{3}{*}{$\begin{array}{l}\text { キ } \\
\text { 地) } \\
\text { 種 }\end{array}$} & \multirow{2}{*}{\multicolumn{3}{|c|}{$\begin{array}{c}\text { 砂, 粘 土 } \\
\text { (一般の沖積層) }\end{array}$}} & \multicolumn{6}{|c|}{ 軟 弱 地 盤 } \\
\hline & & & & & & & \multicolumn{3}{|c|}{$N=2 \sim 5$} & \multicolumn{3}{|c|}{$N<2$} \\
\hline & & & & & 1 & 種 & 第 & 2 & 種 & 第 & 2 & 種 \\
\hline $2 \sim 10 \mathrm{~m}$ & 第 & 2 & 種 & 第 & 2 & 種 & 第 & 3 & 種 & 第 & 4 & 種 \\
\hline $10 \sim 25 \mathrm{~m}$ & 第 & 2 & 種 & 第 & 3 & 種 & 第 & 4 & 種 & 第 & 4 & 種 \\
\hline $25 \mathrm{~m}$ 以上 & 第 & 3 & 種 & 第 & 4 & 種 & 第 & 4 & 種 & 第 & 4 & 種 \\
\hline
\end{tabular}

\begin{tabular}{|c|c|c|}
\hline 洪積層の厚さ & 種 & 別 \\
\hline $10 \mathrm{~m}$ 以下 & 第 1 & 種 \\
\hline $10 \mathrm{~m}$ 以上 & 第 & 種 \\
\hline
\end{tabular}

表-6 重要度係数（鉄道土木施設）

\begin{tabular}{|c|c|c|c|c|}
\hline 重 要 度 & I & II & III & IV \\
\hline 係 & 1.2 & 1 & 0.8 & 0.6 \\
\hline
\end{tabular}

4）港湾構造物

港湾構造物の設計基準は「港湾工事設計要覧」11) に規定されているが，現在設計基準全般に 亘つて改訂作業が進められており，耐震規定に関する部分については改訂案が既に作成されて いるのでこれを紹介する。「港湾設計基準（案）」12)によれば，地震力は死荷重および積載荷重 と設計震度の積で求められ，水平方向にの夕作用するものとされている．また活荷重に関して は, 軌条走行式クレーン荷重で, それにかかる地震力が構造物に影響を与えるもののみ考慮す るよう定められている。

設計震度は国鉄土木施設と同様，地域別，地盤別，重要度別に定められるもので次式によつ て求められる。 
設計震度 $=$ 地域別震度 $\times$ 地盤種別係数 $\times$ 重要度係数

上式中の地域別震度は 表-7 に, 地盤種別係数は表 -8 に, 地盤種別分類表を表 -9 に, 重要 度係数它表-10 そそれぞれ示す。

港湾構造物の耐震設計は上述の設計震度を用いた震度法によつて行なわれるのを原則とする が, 鋼杭栈橋のようなフレキシブルな構造物の場合には, 構造部材の塑性領域迄考慮した地震 応答に基づく動的設計 ${ }^{13)}$ を行なう場合もある.

表-7 地域別震度（港湾構造物）

\begin{tabular}{|c|c|c|}
\hline 第 1 地区 & $\begin{array}{l}\text { 北海道（根室, 釧路, 十勝） } \\
\text { 関 東 (千葉, 東京, 神奈川) } \\
\text { 中 部（静岡, 愛知） } \\
\text { 近 畿 }\end{array}$ & 0.15 \\
\hline 第 2 地区 & $\begin{array}{l}\text { 北海道 (後志, 渡島, 留萠 } \\
\text { 東 }) \\
\text { 北 } \\
\text { 関 東 (茨城) } \\
\text { 中 部 (新鶕井, 富山, 石川, } \\
\text { 四 国 } \\
\text { 中 国 (鳥取, 岡山, 広島) }\end{array}$ & 0.10 \\
\hline 第 3 地区 & $\begin{array}{l}\text { 北海道（宗谷, 網走) } \\
\text { 中 国 (島根, 山口) } \\
\text { 九 州 }\end{array}$ & 0.05 \\
\hline
\end{tabular}

表-8 地盤種別係数（港湾構造物）

\begin{tabular}{c|c|c|c|c}
\hline \hline 地盤種別 & 第 1 種地盤 & 第 2 種地盤 & 第 3 種地盤 \\
\hline 係 数 & 0.8 & 1.0 & 1.2 \\
\hline
\end{tabular}

表-9 地盤種別（港湾構造物）

\begin{tabular}{|c|c|c|c|}
\hline 層の厚さ & 砂レキ層 & $\begin{array}{l}\text { 一般の砂, } \\
\text { 粘土地盤 }\end{array}$ & 軟弱地盤 \\
\hline $5 \mathrm{~m}$ 以下 & 第 1 種 & 第 1 種 & 第 2 種 \\
\hline $5 \sim 25 \mathrm{~m}$ & 第 1 種 & 第 2 種 & 第 3 種 \\
\hline $25 \mathrm{~m}$ 以上 & 第 3 種 & 第 3 種 & 第 3 種 \\
\hline
\end{tabular}

表-10 重要度係数（港湾構造物）

\begin{tabular}{c|c|c|c}
\hline 重要度 & I & II & III \\
\hline 係 数 & 1.5 & 1.0 & 0.5 \\
\hline
\end{tabular}

以上代表的な土木構造物の耐震規定の概要を述べたが，乙れらを一括して整理すると表-11 のようになる。これによると，それぞれの構造物の設計震度がいかなる要素（因子）を重視し て定められているかが明瞭であり，各々の特徴をうかがうことができる。

\section{2. 最近の大地震による土木構造物の被害}

土木構造物はこれ迄に数多くの地震によつて，しばしば多くの被害をうけて来たが，ここで は記憶に新らしい新潟地震による被害について述べることにする.

新潟地震によつて被災した土木構造物は港湾施設, 橋梁, 水道施設, 鉄道, 道路, 堤防, 発 送電施設, 空港, 農業土木施設等であり, 新潟地震による被害の特性は新潟特有の地盤による ものとの印象が強い.

\section{2-1 港湾施設}

新潟地震およびこれにより発生した津波による港湾施設の被害 ${ }^{14)}$ は新潟港, 酒田港他 9 港に 


\begin{tabular}{|c|c|c|c|c|}
\hline 进 & 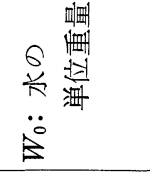 & 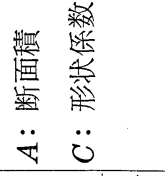 & & 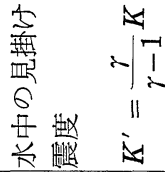 \\
\hline 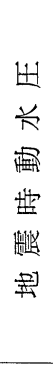 & 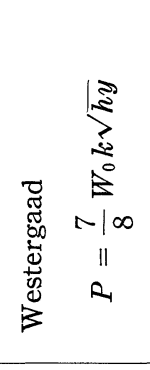 & 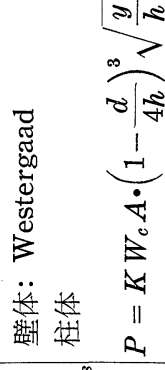 & 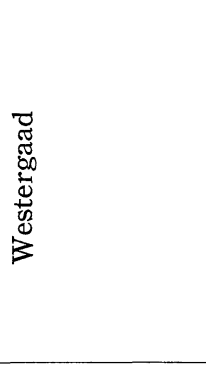 & 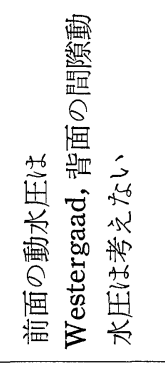 \\
\hline 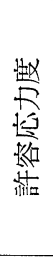 & $\frac{4}{10}$ & 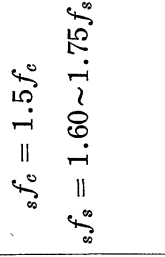 & $\stackrel{+}{i}$ & \\
\hline $\begin{array}{l}\text { 軒 } \\
\text { 掩 } \\
\text { 斯 }\end{array}$ & $\begin{array}{l}\text { 㽞 } \\
\text { 細 }\end{array}$ & 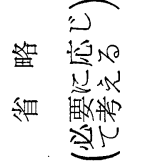 & $\begin{array}{l}\text { 㽞 } \\
\text { 緛 }\end{array}$ & 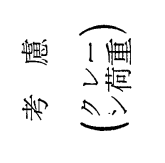 \\
\hline 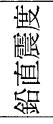 & $\begin{array}{l}\text { 嫘 } \\
\text { 领 }\end{array}$ & $\underset{ }{\stackrel{N}{N}}$ & $\begin{array}{l}\text { 嘿 } \\
\text { 緲 }\end{array}$ & 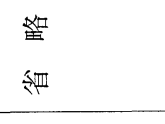 \\
\hline 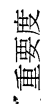 & 2 & 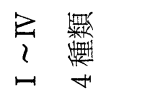 & 2 & 筮 \\
\hline 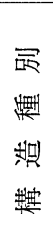 & 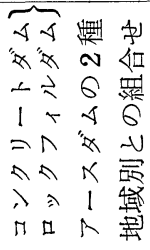 & 2 & 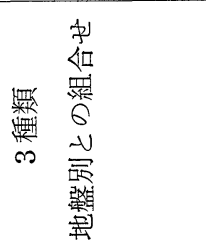 & + \\
\hline 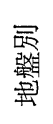 & 2 & 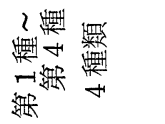 & 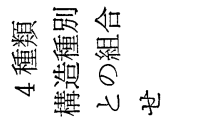 & 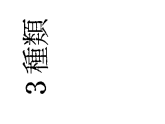 \\
\hline 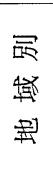 & 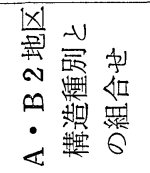 & 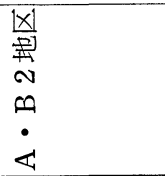 & 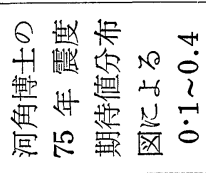 & $\begin{array}{l}\dot{0} \\
\dot{\varphi} \\
\dot{\varphi}\end{array}$ \\
\hline 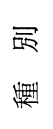 & 4 & 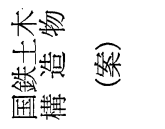 & 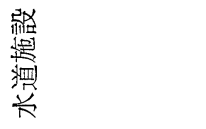 & 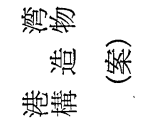 \\
\hline
\end{tabular}


および，被害額 220 億円に達したが，中でも新潟港は壞滅的な打撃を受け，総額 218 億円に 達する被害を蒙つた。被災した施設は繋船岸, 護岸, 海岸堤防, 防波堤, 導流堤, 水制, 灯 標, 航路等の他上屋, 倉庫, 荷役機械, 臨港道路, 鉄道等多くの種類におよえだ.また信濃川 護岸, 臨港㙞頭岸壁および一部の海岸堤防が地震により倒壊したため, 続いて来襲した津波に よつて，背後の市街地が広範囲に亘つて浸水した。

上記の被災した港湾施設の中でも特に被害の著しかつた撃船岸, 護岸の被害の一般的傾向は 次の通りである.

撃船岸, 護岸を通じて, 矢板構造が比較的多いが, 典型的な破壞の様式は岸壁頂部の沈下, 法線のはらみ出しであつて, 被害断面の調査結果によれば, 前傾形式の破壊が一般的である. 矢板壁の根入れの不足による破壞は余り見られず，大部分の被害の原因は控壁の抵抗不足によ るものであり，現行基準に基いて設計された新らしい岸壁は控壁の抵抗を充分見込えであるた め被害は軽微であつた。 また一部の小型岸壁, 護岸では tie rod の切断が確認された個所も ある, 臨港㙞頭のウェル構造岸壁は前傾, 沈下が著しく, これは振動時の支持力不足によるも のである. ウェルの間の中間部にある杭栈橋の部分は, 両側のウェルの影響で前傾, 沈下した ものと思われ，それ自体としてはウェルより安定なものと思われる。これは両者の根入れ長の 差によるものと思われ，新潟のような地盤では根入れの梁い構造ほど安定であるということが できよう。このことは全く同形式の岸壁でも，水深の浅いものほど被害がひどいという事実か らも肯定することができ，新潟港の復旧に関する基本方針にも，このような考方方導入され ている、また背後に土圧を受けない形式の構造に被害が少ないことは明らかな傾向であり, 栈 橋, ドルフィン等には被書が少なく, 重力式, とくにブロック構造に被害が顕著であつた。

地震による埋立土の沈下が著しかつたのも今回の地震の特微で, 特に上屋, 倉庫の被害はこ れに起因するものが多いと思われる，既往の地震のさい見られた円弧すべりによる破壞は，ご く一部它除いては見られず，乙の点も新潟の地盤の特性をよくあらわしていると考元られる。

土質と震害状況に関する一般的傾向として, 砂地盤の $N$ 值が小さい㴗ど被害は大きく，ま た大きな $N$ 值を示す地盤でも，局所的に弱い層をはさんでいる場合には沈下などの被害を受 けやすいことが見られた。

結論として，新潟地震による港湾の被害の原因として考えられることは数次に亘る地盤沈下 対策のための嵩上工事の結果, 構造物の地震に 対する安全率が 新造構造物に 比し下趈つたこ と, 表層附近の土の強度が地震時に低下したとと等があげられる.

今回の地震の被害の特色としては，今までに見られなかつた全く新らしい形の被害はなかつ たが，砂質地盤における震害の特性として実験室における研究から推測されていた形式，ある 
いは過去の震害で局所的に発生した形式の被害が広範囲, 大規模に起つたことを挙げることが できよう.

\section{2-2 橋 梁}

新潟地震による橋梁の被害 ${ }^{15)}$ は新潟, 山形, 秋田, 福島の 4 県におよんだが, 新潟県特に信 濃川, 阿賀野川の下流地域において顕著であつた。

震源地より約 $100 \mathrm{~km}$ の範囲内で 93 橋について調査した 結果つぎのような様相が見られ た。

1）橋梁の被害は気象庁発表の震度分布に大体従うが，局所的には基礎地盤の性状による影 響が大きく表われていた。

2）各種型式の被害率はほぼ同程度で，どの型式が耐震的であると言う結論はでなかつた。

3）地盤上層で地下水位以下の緩い砂層では流動化のために支持力が減少し, 下部構造の傾 斜，沈下や橋台，翼壁のすべり出しなどが見られる.

4）砂地盤地域における橋梁の被害が目立つたが，その場合でも基礎が $N$ 值で $25 \sim 30$ の 層に十分根入れされていたものは被害が僅少であつた。

5）上部構造の被害は下部構造の変状により誘発されたものが多く, 内容的に見れば，被害 の大きいものは落橋の 3 橋（昭和大橋，新潟駅東跨線橋，新松浜橋）と八千代，万代の 2 橋であつたが，その他のものでも設計や施工上弱点のあるものでは，その部分に被害が見 られ，特にケタ支承部，伸縮継ぎ手，高欄なぞ局部的な被害が多く見られた。

なおこのような大きな被害をおこした主な原因としては前述のような砂質地盤の流砂現象の 外, 地震動の特性というものが考えられる。

新潟市川岸町の県営アパート地下室に設置されていた強震計記録の応答スペクトルの解析結 果によると，新潟地震では現在まで得られたいくつかの，新潟地震以外の地震動に対する平均 的な応答スペクトルと比較して次のような特異性が見られる。すなわち，

（1）構造物の固有周期 $T$ がほぼ 1.0 秒以下では新潟地震記録の場合と平均応答スペク トルによる場合とでは応答加速度の増幅率においてほとんど変りがない.

（2） $T$ がほぼ 1.0 秒以上になると, 平均応答スペクトルによる応答の場合よりも新潟地 震記録による応答の方が大きい応答を示している。しかし $T$ が 6 秒以上の長周期になれ ば新潟地震による応答の增幅率は平均応答の場合に近づく傾向がある。

剛性が大きい万代橋では基礎地盤の変状と支持力減少が被害を大きくした主なる原因と考え られるが，昭和大橋や八千代橋では構造物の地震応答性状も被害に大きな影響を与えたものと 思われる。 


\section{2-3 鉄 道}

国鉄の被害 ${ }^{16)}$ は新潟支社管内では新潟駅, 水没した万代線, 新潟港線, 東新潟港線の三つの 貨物線, 白山駅を中心とした越後線および羽越線を中心として生じた。羽越線は秋田管理局管 内においても出戸，両目間において $15,000 \mathrm{~m}^{3}$ におよぶ高築堤崩壞をおこしている.

他に盛岡, 仙台, 高崎, 長野, 金沢の各管理局管内に拉よえで括り, 施設関係の被害のみで 約 67 億円にのぼる被害が生じた.

次に主な線の被害の概要は次の如くである。

(1) 信越本線

新潟駅入口の笹口こ線道路橋が落下し，これが新潟駅の使用をさまたげた。また構内のホー ムが波打つて変形し，これは本屋側ほど大であつた。地下道は水と共に噴き出た砂が堆積し た，次に新潟運転所は一般に基礎地盤が波打ち，砂が入りこんでいて本復旧には時間が要する ようであつた。架線, 電柱の被害は西方の部分が大である。新潟駅構内以外では柏崎, 長岡間 の第二塚山ずい道が変状をおこした。

（2）万代線, 新潟港線, 東新潟港線

沈下と津波による浸水で当分復旧不能といわれる被害をうけた。

(3) 越後線

全般に路盤沈下があるが，特に関屋，新潟間は $5 \sim 6 \mathrm{~m}$ の築堤が約 $3 \mathrm{~m}$ も沈下陥没し，約 $16,000 \mathrm{~m}^{3}$ を失つた。橋梁も軒並に被害を受けたが信濃川橋梁は 1 号橋脚が約 $8^{\circ}$ も傾き開通 のネックとなつた。 また白山駅の盛土の中の地下道が盛土の沈下で破壞し, 使用不能となつ た.

(4) 羽越線

秋田局管内の出戸，両目間の高さ $7 \sim 8 \mathrm{~m}$ の築堤が延長 $160 \mathrm{~m}$ にわたつて約 $15,000 \mathrm{~m}^{3}$ 流 失した。他の主なものは村上，酒田間でずい道の変状のためセントルを入れたものが 3 カ所も あつた. しかし開通の最大のネックとなつたのは勝木, 府尾間の切取崩壊で, 地震後の降雨に より被害が大きくなり復旧を遅れさせた。

列車の転覆事故はなかつたが進行中の列車の運転手が如何にして地震を感知し，いかなる処 置をとつたかの調査が行なわれ，興味ある結果が得られた ${ }^{17)}$.

\section{2-4 その他の土木構造物}

水道施設は配水管の被害がひどく，市民生活に大きな影響を与えた。 また空港は浸水と滑走 路に生じたクラックにより，使用不能となつた。堤防は沈下を生じ，縦のクッラクが生じた。 堤体材料の中で粘性土を主としたものの方で砂質土に比べて被害が小さく，また堤防と他の堅 
い構造物, たとえば橋梁, 閘門, 水門等とのつなぎ目では堤防の沈下, クラックの発生がはな はだしかつた。これはそれぞれの振動性状の不連続性によるものと思われる。また新潟地震の 被害状況から判断すると土袞安定工法の効果がかなり顕著にあらわれていたととは注目に值す る。すなわち，ゆるい砂地盤上に作られたオイルタンクの被害状況がバイブロフローテーショ ンの施工の有無によつて，非常に異なる事実が見られた。

\section{3. 土木分野における地震工学研究の展望}

土木分野における地震工学上の問題点は応用地震学に属する課題, あるいは建築と共通する 課題にも問題が多い.すなわち設計で考えねばならぬ地震の性質あるいはとれが地盤の特性と ぞう結びつくか等種々ある。しかしながら土木構造物に特有な問題もしくは特に関係の深い課 題を挙げると次のようになる.

\section{3-1 土質力学および基礎工学に関連する諸問題}

（1）土の振動時の強度（剪断抵抗）および沈下

これは後述の土圧，支持力に深い関連を有する基本的事項であつて設計の際大きな問題とな る.これに対する研究は最近特に盛んである.

（2）地震時土圧

現在クーロン系の岡部 ${ }^{18)}$ ・物部 ${ }^{19}$ 公式が使われている. 港湾で注問題が多い. 主働土圧 (外 力としての）と抵抗としての受働土圧があり，それぞれ地震時には常時より危険側の值をと る. 松尾博士 ${ }^{20)}$ 以来実験的研究がさかんで, 現在九大, 名大, 港湾技研等において研究が進め られているが，未だ確定的な結論は得られていない，一方地震時土圧の問題を理論的な手法で 解明しょうと言う試みも若干行なわれており, これには主として塑性破壞, 粘弾性理論等が応 用されている。

（3）地震時動水圧

壁体に働く動水圧はダム, 港湾構造物等の分野で問題があり, 実用公式としてはウェスター ガードの簡易公式が用いられている，また橋脚等のような柱体に働く動水圧の問題は全体の安 定，構造部材の応力のほかに 振動性状に関戛がある付加質量の問題として 取り上げられてい る. 一方裏込めの間吵水の動水圧の問題は港湾構造物の場合主として問題となるが, 現状では 地震時土圧を算定する場合に採用する設計震度を水中における見掛けの震度をとることによつ ておぎなつている.

（4）その他の問題

以上のほか, 土木構造物の耐震設計に関連のある土質力学, 基礎工学の問題としては, 地盤 
の支持力, 砂質土の流動化, 斜面の安定, 基礎の交持力および横抵抗等の問題があり, 研究成 果の一部は実用設計にとり入れられている.

\section{3-2 各種土木構造物の耐震性の研究}

（1）各種土木構造物の振動性状の研究

主として動的設計の資料とするため，各分野でとれぞれの構造物の振動性状に関して活発な 研究が行なわれている。

（2）各種土木構造物の被害形式, 破壊機構の研究

震害をうけた各種構造物の被害形式の調査ならびに破壞機構の研究を行なうことによつて, 震害を最小限に食い止め, あるいは復旧を容易ならしめるための效果的対策を樹立すべく努力 がはらわれている。

(3) 耐震工法の研究

最近首都高速道路公団では SU ダムパー ${ }^{21)}$, オイルダムパー22) 等を採用して高架橋の耐震 性を図つた。

\section{3-3 土木分野における地震工学研究の最近の動向}

1965 年 1 月ニュージーランドのオークランドおよびウェリントンで開催された第 3 回世界 地震工学会議に提出された論交 ${ }^{23)}$ の内容から最近の土木分野における地震工学研究の動向を紹 介する。

第 3 回世界地震工学会議に際して設けられた 5 項目の議題のうち, 土木分野に関係があるの は次の 3 議題である。すなわち,

議題 I 地震問題に関連する地盤, 基礎条件

議題 II 構造物の地震応答と計測器械

議題 IV 耐震設計・構造および法規

議題 I に属する論文を分類すると次のようになると考えられる。

（1）土の動的性質に関する研究

この分類に属するものとして, 砂の流動化現象をとり扱つた論文が一篇, 粘土の変形特性 （動荷重による）の論文二篇, 震害との関連で土の力学的性質を扱つたもの一篇, 地震時の間 隙動水圧の問題一篇, 都市計画, 産業計画に関連した地盤調査を主題とした論文一篇および地 震荷重による土の支持力, 沈下をとり扱つたもの一篇, 計 7 篇をあげるととができる.

（2）構造物の動的応答に関連した基礎地盤の性質

この分類に属すると考えられる論文 3 篇を挙げることができるが，何れも直接土木構造物を 対象としたものではない. 
（3）土構造物 (Earth Structure) の振動

$\mathrm{PC}$ 管式防波堤およびアースダムの振動問題および耐震性を論じた論文がそれぞれ一篇宛提 出された.

（4）成層地盤の地震応答

(5) Geotectonics

(4)，(5) はいずれも土木分野とは直接関連のない論文である.

次に議題 II 属する論文は毎回非常に多いのが通例であるが今回も50 篇に近い論文が堤出 された. Session Reporter である Housner 教授の分類によれば，議題川に属する論文は次 のように分類することができる。

\section{（1）構造物の非線型応答}

この分類に属する論文のうち, 直接土木構造物を対象としたものは, 塑性ヒンデをもつ骨組 構造の地震応答計算に関する論文一篇がある。

（2）弾性構造物の応答計算

土木分野の論文として粘弾性体の振動問題をとり扱つた論文一篇がある.

（3）特殊な構造物の動的性質

この分類に属するものの中には土木構造物を主題としたものが多い.すなわち橋梁関係では 橋脚, 橋台の振動解析をする上で重要な二自由度系の応答を取扱つた論文一篇, 水中橋脚に作 用する動水圧を主題とした論文 2 篇およびアーチ橋の振動解析, 模型実験等の論文一篇が含采 れている. ダムに関してはアースダムの地震応答を観測し, フーリェ分析を行なつて, 各成分 の卓越周期を求め, ダム堤体の加速度分布, 減衰常数等を論じた論文一篇挨よびアーチダムの 模型および実物実験を行ない，モード形状，固有周期等を定めた論文一篇が含まれている。こ のほか，この分類に属する論文として，杭基礎および杭構造の振動性状，矢板岸壁の模型振動 実験等を内容とした論文各一篇が含まれている。

（4）構造物の動的性質の実験的決定

（5）構造物の振動解析

（4）（5）の分類に属するものは主として 建築物を対象としたものが多く，土木構造物を対 象としたものは含まれない.

議題 IV に属する論文は，大別すると，（1）建築物を主体とするもの．（2）特に建築物と 表現されていないが実質的に建築物を対象とした論文. (3) 土木, 建築構造物に共通した一 般的論文. (4) 土木構造物を主対象とした論文とに分けることができる. 土木構造物または これに類以の構造物を主な対象とした論文は 8 篇あり, 給水塔の振動実験, 耐震設計を主題と 
した論文が一篇, 高炉の耐震設計を取扱つた論文一編があり，ダム関係では溥いアーチダムの 地震荷重の決め方を述べた論文，ダム一般の耐震設計の問題点をとり上げ，ダムの耐震規定を 述べた論文，アースダムの地震時安定性を論じた論文等 4 篇がこれに含まれている。また橋梁 関係では長径間吊橋の振動解析，耐震設計法を論じた論文および橋脚基礎に大径鋼管を用いた 設計例等の論文各一篇が含まれている.

全体として土木分野の研究発表は量的には余り多くなかつたが，3-1 および 3-2で述べた研 究項目に対応する論文が非常に多く、ニュージーランド会議で発表された論文の内容からも現 在の研究の動向を充分にうかがうことができると考えられる。

\section{参 考 文 献}

1) 佐野利器, “家屋耐震構造論”震災予防調查会報告 第 83 号, 1916.

2) 林 聡, 宫島信雄, “各種擊船岸の振動性状に関する研究（第 1 報）——神戸港第 7 突堤の振動 性状について—”, 運輸技術研究所報告 Vol. 11, No. 1, 1961 年 12 月.

3）福内大正，山下生比古，“津波防波堤の耐震性に関する研究”，(未刊行）

4) 土木学会, “土木構造物の耐震設計指針 (案)” 1965 年 10 月.

5) G. W. Housner, R. R. Martel and J. L. AlFord, "Spectrum Analysis of Strong-Motion Earthquake", Bulletin of the Seismological Society of America, Vol. 43, No. 2.

D. E. Hudson, "Response Spectrum Techniques in Engineering Seismology", Proceedings of the 1st World Conference on Earthquake Engineering, 1956.

6) G. W. HousneR, "Behavior of Structures during Earthquakes", Proceedings of the American Society of Civil Engineers, Vol. 85, No. EM 4, 1959.

7) 建設省土木研究所, “地震荷重飞関する調査——吊橋の地震荷重 (その 2) —”, 1964 年 10 月.

8）田治見宏, “耐震理論北関する基礎的研究”, 東京大学生産技術研究所報告. Vol. 8, No. 4, 1959.

9) K. KANAI, "An Empirical Formula for the Spectrum of Strong Earthquake Motion", Proceedings of the 2nd World Conference on Earthquake Engineering, 1960.

10) The Japan Society of Civil Engineers, "Earthquake Resistant Design for Civil Engineering Structures, Earth Structures and Foundations in Japan". 1964.

International Association for Earthquake Engineering, "Earthquake Resistant Regulations, A World List. 1963.

11）日本港湾協会『港湾工事設計要覧」 1959.

12）日本港湾協会「港湾設計基準 (仮題)」未刊行.

13) 山本隆一他「鋼杭栈橋の耐震設計法」未刊行.

14）運輸省港湾局, 第一港湾建設局, 港湾技術研究所「新潟地震津波調查報告」 1964 年 8 月. 運輸省港湾局, 第一港湾建設局, 港湾技術研究所「新潟地震港湾被害報告」(第 1 部) 1964 年 9 月. 運輸省港湾局, 第一港湾建設局, 港湾技術研究所「新潟地震港㴒被害報告」(第 2 部) 1965 年 3 月.

15）建設省土木研究所「新潟地震調查報告」土木研究所報告第 125 号 1965 年 6 月.

16）鉄道技術研究所「新潟地震調查報告」鉄道技術研究所報告 No. 448, 1964 年 11 月.

17) 土木学会耐震工学委員会「地震と列車の安全」土木学会誌 Vol. 50, No. 4, 1965 年 4 月.

18) 岡部三郎 "General Theory on Earth Pressure and Seismic Stability of Retaining Walls and Dams” 土木学会誌 Vol. 10, No. 6, 1924 年.

19)物部長穂「土木耐震学」改訂版 1952 年.

20）松尾春雄「地震時土圧の分布に関する実験的研究」土木学会誌 Vol. 27, No. 2, 1941 年.

21) Shunzo OKAMOTo and Yukitaka UEmaE "Aseismic Bridge Structure by Elastic Support Using Tie Members (SU Damper Method)", Proceedings of the Symposium on the New Ideas in Structural Design.

22) Shunzo Oкамото and Yukitaka Uemae "Aseismic Bridge Structure by Oil Damper Method", Proceedings of the Symposium on the New Ideas in Structural Design.

23) "Proceedings of the 3rd World Conference on Earthquake Engineering", $1965 \mathrm{New}$ Zealand. 